\title{
The Role of Tertiary Education in Developing Local Communities: The Case of Al-Majma'ah Town, Saudi Arabia
}

\author{
Dr. Ibrahim Al-Zuaibir \\ Al-Majma'ah University, Saudi Arabia \\ E-mail: drzuaibir@yahoo.com
}

\begin{abstract}
This research explores the role of education in developing the local community of Al-Majma'ah town in Saudi Arabia. In so doing, it attempts a detailed account of the relationship between education and development. The paper then proceeds to report the development issues that have been addressed by the tertiary education programs in the light of the theories underlying the relationship between education and development.
\end{abstract}

Keywords: Tertiary education, Development, Local communities, Empowering, Extra-curricular activities, Campaign, Academic programs, Transformation, Health programs, Capacity building

\section{Introduction}

In 2004 King Saud University established a Community College in Al-Majma'ah town, which is $180 \mathrm{k} / \mathrm{ms}$ north of the Capital Riyadh, to serve the local community in a variety of ways. First, the college offers two-year academic programs to cater for perceived market needs of the local and surrounding communities. These roughly fall into two categories: market-oriented programs (computer science and accounting) and health programs (Nursing and Medical Devices). Second, it qualifies secondary school graduates who have failed to secure college seats through regular admission so that they pursue their higher education after successfully completing a two-year syllabus in two academic fields: English and Accounting. Third, the College implements a number of awareness-raising activities, including environment preservation, afforestation and anti-smoking campaigns. Fourth, a number of studies have to date been conducted, addressing issues affecting different aspects of local communities. This paper, then, is an attempt to report, document and assess this trend in community development in the light of the relevant literature reported in detail in (2) below.

\section{Education and Community Development}

According to Frank and Smith (1999:12) "community development is planned evolution of all aspects of community well-being" and that it is "a process whereby community members come together to take collective action and generate solutions to common problems". It targets both individuals and groups at large by empowering them with "the skills they need to affect change in their communities" (Wikipedia). "Community development" is often contrasted to "community backwardness" which is characterized by a mismatch between population increase and productivity decrease, infant mortality, poor health and malnutrition (Al-Zuaibir, 2000)

According to Al-Zuaibir community development is a multifaceted process and of accumulative nature whereupon change and transformation occur in people's lives (ibid). Owing to the multiplicity of different aspects of community development, the relevant literature abounds in a variety of approaches to deal with these aspects:

- Community economic development

- Community capacity building

- Social capital formation

- Political participatory development

- Non-violent direct action

- Ecological sustainable development

- Asset-based community development

- Faith-based community development

- Community practice social work 
- Community-based participatory research

- Community mobilization

- Community empowerment

- Community participation

- Participatory planning

Apparently, these approaches are not mutually exclusive, and while they can be implemented individually, they can also be incorporated into a comprehensive development program in order to achieve such desirable results as "higher incomes, longer life expectancy and more education" (Jacobs, 1999). It can be argued that active involvement into such development programs requires that community members must have first acquired a set of social values listed by Jacobs as physical (cleanliness, punctuality), organizational (communication, coordination), psychological (courage, generosity), mental (objectivity, sincerity) and spiritual (harmony, love, self-giving).

It is widely argued that education plays pivotal role in community developments. Some researchers have gone so far as to argue that education is a differentiating factor between the most and least developed communities (cf. Lyson, 2005) as will be shown below. Bokova (2009) points out that "education empowers individuals with knowledge and skills to better lives. More broadly, it opens the way to active citizenship and democratic participation". In that connection, education is not only one the many approaches to community development but also a prerequisite for effective implementation of each and every approach reported above.

The role of education in community development becomes more vital with the increased reliance on technology. Barkely et al (2005:10) maintain that educated labor is a determinant factor in attracting "high technology industries and businesses with significant employment in skilled and technical occupations". So it is argued that that if societies do not "educate some - if not necessarily all- of its members to a high level of technical competence", they "would fail to develop technologically" (livesley, ....), and, thus, cease to be associated with modern communities since technology seems to be the major if not the sole basis of such classification.

Lyson (2005: 23-27) reports a number of advantages that schools can bring to a rural community:

1. Schools are vital to the survival of rural communities.

2. Schools are places for sports, theatre, and other civic activities.

3. Schools are vital to the survival of rural communities.

4. Schools serve as symbol of continuing autonomy, community vitality, community integration, personal control, personal and community tradition and personal and community identity.

5. Viable villages contain schools, dying and dead ones either lack them or do not have them for long.

6. The capacity to maintain a school is a continuing indicator of community's well-being.

7. Schools are a source of employment for village residents.

8. Schools provide social, cultural and recreational opportunities.

9. Schools are places where generations come together and where community identity is forged.

10. Communities with schools are associated with better government services than communities without.

Educational institutions are, then, not just place where students acquire knowledge and professional or vocational training. Viz. they also serve the community at large socially, culturally and economically. It is for reason that education is conceived to be "an agency for secondary socialization" in that "it broadens the individual's experience of the social world. It prepares people b for adult role relationship" (Livesey)

\section{Tertiary Education and Al-Majma'ah Community Development}

For over the last five years Al-Majma'ah Community College has been contributing to the development of the local communities through a number of curricular and extra-curricular activities as reported in (1) above. As to the first type of activities, the college was originally established to serve two purposes. First, it prepares the students through two-year programs to transfer to four-year colleges so that they graduate with a B.A or B.Sc. in the relevant field. Second, it provides the students with two-year post-secondary training leading to as associate degree in fields that are perceived to be in demand. While it is true that curricular activities are exclusively directed to a very small sector of the community, i.e. the students, the possible outcome will result in nativising a 
number of public jobs in health, economic and educational sectors that have for a long time been occupied by foreign personnel.

Generally speaking, community education in Saudi Arabia differs greatly from the universal patterns known in other parts of the world. Kolensnikova (2009:10) informs that "community colleges provide opportunity to receive a post-secondary education to many students who could not attend college otherwise: students from low-income families, first generation students and older students who continue to work full time as they attend college." In Saudi Arabia, the only reason students attend community colleges is their failure to compete for admission in four-year colleges. Thus, community colleges function as a preparatory programs that would enable the students to transfer to bachelor programs. Of course, they could better serve the community if "first generation students and older students" are allowed to attend them.

A number of Saudi students are emotionally attached to their families to the extent that they are reluctant to travel and stay in different cities to pursue college education. In Al-Majma'ah town some students even chose to sacrifice college education despite their outstanding school performance owing to their preference for staying with their families. Thus, Al-Majma'ah Community College has proved to be the best solution for hundreds of students who could have otherwise become educational fall-out.

After the College foundation, most students were enrolled in two-year programs to graduate with an associate degree so that they would never need to transfer to four-year colleges in Riyadh which implies living away from families. Some students travel daily for over one hundred kilometers to attend college in Al-Majma'ah town for the same reason. So one's educational future is bound up with the location of their family. Indeed, Saudi family is conceived to be "the most important social institution" in that it is believed to be play two essential roles in one's life: it functions as the primary basis of one's identity and status, and it is the immediate focus of one's loyalty (Metz, 1992)

Two such curriculum-related activities that have also been addressed to the community at large are research papers and training courses. Where research papers are concerned, they have either been written for publication in specialized journals or read at local and international symposia and conferences where emphasis have always been placed on local issues. The themes of the papers spanned the full range of academic disciplines offered by the College: English language teaching, Linguistics, Accounting, Computer Science, Nursing and Medical devices.

Needless to say, the research findings would serve as living documents that local authorities could use in initiating or modifying existing development plans with respects to the aspect suggested by the relevant research.

\section{Conclusion}

This research has been intended to report and document the role that Al-Majma'ah Community College has been playing to develop the local communities socially, economically and educationally. It has been shown that educational programs of the College have served the local communities in a variety of ways. First, they have provided these communities with training in academic fields that are highly needed, e.g. health-related programs. Second, a number of training courses have directly been addressed to the members of the local communities most of whom were not officially enrolled in the academic programs of the College, e.g. training courses in foreign languages, computer programs, etc. Third, the local communities have linked to the College through a variety of awareness-raining and capacity-building programs such as professional workshops, environment reservation and anti-smoking campaigns.

The years 2009 and 2010 witnessed the establishment of more colleges that have culminated in the foundation of a new university in Al-Majma'ah town, which is expected to have far-reaching consequences for direct and indirect development initiatives to develop the local communities.

\section{References}

Al-Zuaibir, I. A. (2000). The Role of Education in Social Development. Unpublished Paper. King Saud University.

Barkely, D. M. Henry, H. Li. (2005). Does Human Capital Affect Rural Economic Growth? Evidence from the South. In L. J. Beaulien and R. Gibs (Eds.), The Role of Education: Promoting the Economic and Social Vitality of Rural America.

Frank, F. and A. Smith. (1999). The Community Development Handbook: A Tool to Build Community Capacity. [Online] Available: www.hrdc-drhc.gc.ca/community (July 1, 2010). 
Jacobs, G. and H. Cleveland. (1999). Social Development Theory. International Center for Peace and Development. [Online] Available: http://www.icpd.org/development_theory/SocialDevTheory.htm (July 7, 2010).

Livesey, C., (n.d.). The Role of Education in Society: Functionalist Perspectives. [Online] Available: www.sociology.org.uk (July 1, 2010).

Lyson, T. (2005). The Importance of Schools to Rural Community Viability. In L. J. Beaulien and R. Gibs (Eds.), The Role of Education: Promoting the Economic and Social Vitality of Rural America. Southern Rural Development Center.

Southern Rural Development Center Bokova, I. (2009). Address at the opening of the Sixth UNESCO International Conference on Adult Education. Belém, Brazil. [Online] Available: http://unesdoc.unesco.org/images/0018/001863/186301e.pdf (August 17, 2010).

Wikipedia. The Free Encyclopedia. [Online] Available: http://en.wikipedia.org/wiki/Community_development. 